\title{
Nutritional and Biochemical Alterations in Vigna Radiata (Mung Bean) Seeds by Germination
}

\author{
Inamul Hasan Madar ${ }^{1 \dagger^{* *}}$, Amjad Hussain Asangani ${ }^{2 \dagger}$, Shantkriti Srinivasan ${ }^{2 \dagger}$, \\ Iftikhar Aslam Tayubi ${ }^{3}$ and Gideon I. Ogu ${ }^{4}$ \\ ${ }^{1}$ Department of Biotechnology and Genetic Engineering, Bharathidasan University, \\ Tiruchirappalli-620024, Tamil Nadu, India \\ ${ }^{2}$ Department of Biotechnology, National College (Autonomous), Dindigul Road, \\ Tiruchirapalli-620001, Tamil Nadu, India \\ ${ }^{3}$ Faculty of Computing and Information Technology, King Abdul Aziz University, \\ Rabigh, Kingdom of Saudi Arabia \\ ${ }^{4}$ Department of Biological Sciences, Novena University, Ogume, Delta State, Nigeria \\ *Corresponding author; †These author contributed equally to this work
}

\begin{tabular}{|c|c|}
\hline & A B S T R A C T \\
\hline Keywords & \multirow{6}{*}{$\begin{array}{l}\text { Mung bean (Vigna radiata), a rich source of many nutrients with potential } \\
\text { health benefits is a commonly used functional food in India. The nutritional } \\
\text { composition of Vigna radiata seeds were estimated in terms } \\
\text { of carbohydrate, free amino acid, protein, chlorophyll and fat content pre } \\
\text { and post germination to assess the biochemical changes in seeds. They were } \\
\text { found to have slightly higher carbohydrate content }(0.021 \mathrm{mg} / \mathrm{g}) \text { after } \\
\text { germination. The amino acid }(0.239 \mathrm{mg} / \mathrm{g}) \text { and protein content }(0.207 \\
\text { mg/g) were appreciably increased compared to dry seeds. There was an } \\
\text { insignificant difference in the fat, chlorophyll a and b contents of pre and } \\
\text { post germinated seeds. These results suggest that the nutritional content and } \\
\text { quality of the seeds of Vigna radiata improves after germination. }\end{array}$} \\
\hline $\begin{array}{l}\text { Mung bean, Vigna } \\
\text { rudiata, Nutrition, } \\
\text { Germination. }\end{array}$ & \\
\hline Biochemical composition, & \\
\hline $\begin{array}{l}\text { Protein, Amino acid, } \\
\text { Carbohydrate, } \\
\text { Chlorophyll. }\end{array}$ & \\
\hline Article Info & \\
\hline $\begin{array}{l}\text { Accepted: } \\
\text { 10 July } 2017 \\
\text { Available Online: } \\
\text { 10 September } 2017\end{array}$ & \\
\hline
\end{tabular}

\section{Introduction}

Pulses belonging to the Leguminosae family have been used as food for thousands of years. Also known as legumes, they have high protein content and are easily digestable (Munoz et al., 1996). Pulses are said to be the poor man's meat and are grown worldwide for consumption due to their high nutrition and low cost aiding in overcoming protein malnutrition in developing countries like
India (Manay and Shadaksharaswamy, 2001). They are also rich in carbohydrate, vitamins and minerals such as calcium, magnesium, zinc, iron, potassium and phosphorus. They restore soil fertility and climate change through their nitrogen-fixing properties. They can be stored in dry and dark conditions for prolonged use. India is the largest producer, consumer and importer of pulses in the world. 
Among pulses, Mung bean, known as Green gram, Vigna radiata or Phaseolus aureus, is cultivated in India, China, Pakistan, Thailand, Indonesia, Burma, Philippines, Bangladesh, Vietnam, Laos, Cambodia and in hot and dry areas of Southern Europe and United States (Verma et al., 2017). In India, it is produced in Karnataka, Andhra Pradesh, Tamil Nadu, Maharashtra, Orissa, Rajasthan, Uttar Pradesh, Gujarat, Madhya Pradesh, West Bengal and Punjab constituting $11.48 \%$ of all pulses (Yadav et al., 2014). It has carbohydrate (51\%), protein (24-26\%), mineral $(4 \%)$, vitamins $(3 \%)$ and fat $(1 \%)$ (Afzal et al., 2008). It has bright green edible legume seeds which ripens uniformly and can be eaten raw or cooked. Mung bean seeds are an invaluable source of digestible protein for vegetarians (AVRDC, 2012).

Along with the nutritional factors, pulses also contain flatulence causing raffinose family oligosaccharides, phytate, heat-stable and heat-labile antinutritional and toxic factors (Salunkhe, 1982). Various pulse processing methods like presoaking, germination or fermentation reduce these factors making legumes as an inexpensive and nutritious human food.

Germination activates biosynthetic enzymes that remove or decrease antinutritional and indigestible factors in legumes thereby enhancing its nutritive value (Bau et al., 1997). Germination was effective in decreasing fat, total carbohydrate, antinutritional factors and total ash contents while increasing crude protein compared to cooked mung bean seeds and higher retaining of all minerals (Mubarak, 2005). Germination of mung beans causes significant changes in metabolite contents, such as breakdown of complex macromolecules like starch, sugars and proteins into smaller and more digestible molecules, decreased concentration of antinutritional factors and increased levels of free amino acids (Chang \& Harrold, 1988;
Labaneiah and Luh, 1981; Kataria et al., 1989; Chau and Cheung, 1997).

Biochemical changes due to germination cause synthesis and accumulation of active compounds such as polyphenols, saponins, vitamin $\mathrm{C}$ etc. from macromolecular substances supporting absorption and utilization which provides antioxidant, antimicrobial, anti-inflammatory, antidiabetic, antihypertensive, antihypertensive and antitumor activities along with nutritive benefits (Tang et al., 2014). Thus, use of mung bean as a nutrient rich food source is of particular interest. But, research on studying the alterations in its nutritional compostion on germination is limited. Thus, the objective of this study was to investigate the effect of germination on biochemical composition and nutritional content of mung bean seeds.

\section{Materials and Methods}

All reagents used in this work were of analytical grade. Double distilled water was used for solution preparation.

\section{Seed collection}

The seeds of Vigna radiata (mung bean) were procured from local retailers in Kumbakonam, cleaned thoroughly and used for further studies.

\section{Seed treatments}

Mung bean seeds were used to study interaction between crude extract and treated samples. $250 \mathrm{mg}$ of seeds were soaked in water in 1:3 ratio (w/v) for over $24 \mathrm{~h}$. Soaked grains were then dried at $45{ }^{\circ} \mathrm{C}$ and ground to pass a $200 \mu \mathrm{m}$ screen. Another portion (250 $\mathrm{mg})$ was immersed in water 1:3 (w/v) overnight and grains were spread on trays, bound with cloth at room temperature $\left(25{ }^{\circ} \mathrm{C}\right)$ for one week. It was moistened by water spraying at frequent intervals. After 
germination, the seeds were dried separately at $45{ }^{\circ} \mathrm{C}$ to constant weight and powdered. One part $(250 \mathrm{mg})$ not subjected to any treatment served as a control (dry or pregerminated seeds).

\section{Extraction and estimation of total carbohydrates}

$0.5 \mathrm{~g}$ of powdered sample was homogenized with $10 \mathrm{~mL}$ of $80 \%$ ethanol. The insoluble residue was removed by centrifuging at 3000 $\mathrm{g}$ for $15 \mathrm{~min}$. The precipitate was re-extracted with $2 \mathrm{~mL}$ of $80 \%$ ethanol and recentrifuged. The supernatants were pooled and dried under a stream of hot air and residue was resuspended in $5 \mathrm{~mL}$ of water.

Total carbohydrates were estimated by Anthrone method (Sadasivam and Manickam, 2008). Seven cleaned test tubes were taken and marked as Blank, $S_{1}$ to $S_{5}$ and Test. $1 \mathrm{~mL}$ water was used as blank. 0.2 to $1 \mathrm{~mL}$ of working standard was poured in $S_{1}$ to $S_{5}$ tubes respectively. The volume was made upto 1 $\mathrm{mL}$ with water. Next, the given mung bean solution was made upto $100 \mathrm{~mL}$ with water in a standard flask. $1 \mathrm{~mL}$ of this diluted mung bean solution was used as the Test sample. The test tubes were kept in ice waterbath for $10 \mathrm{~min}$. Then $4 \mathrm{~mL}$ of anthrone reagent was added to each test tube and kept in a boiling waterbath for 15 min. Readings were taken at $640 \mathrm{~nm}$.

\section{Extraction and estimation of protein content}

$500 \mathrm{mg}$ of the sample was powdered with 5 to $10 \mathrm{~mL}$ of buffer, centrifuged and the supernatant was used for protein estimation (Lowry, 1951).

0.2 to $1 \mathrm{~mL}$ of working standard and $1 \mathrm{~mL}$ of diluted mung bean extract (Test) were poured in a series of test tubes and the volume was made upto $4 \mathrm{~mL}$ with distilled water. The aliquots were incubated with $5.5 \mathrm{~mL}$ of alkaline copper sulphate reagent in a water bath for $10 \mathrm{~min}$. Then, $0.5 \mathrm{~mL}$ of Folin's reagent was added and incubated at room temperature for $30 \mathrm{~min}$ for change to blue colored product. The blank contained $4 \mathrm{~mL}$ of distilled water with $5.5 \mathrm{~mL}$ alkaline copper sulphate and $0.5 \mathrm{~mL}$ Folin's reagent. The optical density of solution was read at 650 $\mathrm{nm}$.

\section{Extraction and estimation of total free amino acids}

$500 \mathrm{mg}$ of mung bean sample was ground with a small quantity of acid-washed sand in a pestle and mortar. 5 to $10 \mathrm{~mL}$ of $80 \%$ ethanol was added to this homogenate, then filtered or centrifuged to obtain clear filtrate or supernatant. The extraction was repeated twice with the residue and all the supernatants were pooled together. The volume was reduced by evaporation and the extract was used for quantitative estimation of total free amino acids.

$1 \mathrm{~mL}$ ninhydrin solution was added to $0.1 \mathrm{~mL}$ extract and the volume was made upto $2 \mathrm{~mL}$ with distilled water. Tube was heated in a boiling waterbath for $20 \mathrm{~min}$. $5 \mathrm{~mL}$ of the composition was added and contents were mixed. After $15 \mathrm{~min}$ Intensity of the purple coloured mixture was measured at $570 \mathrm{~nm}$.

\section{Extraction and estimation of chlorophyll}

$1 \mathrm{~g}$ of sample was ground well with $20 \mathrm{~mL}$ of $80 \%$ acetone and centrifuged at 5,000 rpm for $5 \mathrm{~min}$. The supernatant was transferred to a $100 \mathrm{~mL}$ volumetric flask. The residue was grounded with $20 \mathrm{~mL}$ of $80 \%$ acetone, centrifuged again and the supernatant transferred to the same flask. The procedure was repeated until the residue became colourless. The mortar and pestle was washed thoroughly with $80 \%$ acetone and clear washings were collected in flask. The volume 
was made upto $100 \mathrm{~mL}$ with $80 \%$ acetone (More and Borkar, 2016).

Chlorophyll content was estimated using method by Arnon (1949). Absorbance of the solution was measured at 663 (chl a) and 645 (chl b) nm with the solvent (80\% acetone) as blank. Absorption coefficients for chlorophyll $a$ and chlorophyll $b$ were used to calculate the chlorophyll concentrations.

\section{Extraction and estimation of fat content}

The dry seed sample was weighed accurately in a petridish and extracted with twice volume of anhydrous ether. The extract was filtered and transferred into a weighed conical flask. It was dried in an oven at $80-100{ }^{\circ} \mathrm{C}$, cooled and weighed again.

\section{Statistical analysis}

Data were expressed as mean \pm standard deviation (SD) for triplicates. Biochemical analysis between control and test was subjected to statistical analysis by t-test at 5 $\%$ level of significance.

\section{Results and Discussion}

Figure 1 showed the dry and germinated seeds of Vigna radiata (mung bean).

The nutritional contents of mung bean seeds are depicted in Table. 1-6. the germinated seeds showed $0.021 \mathrm{mg} / \mathrm{g}$ carbohydrate content in the sample while dry seeds had $0.017 \mathrm{mg} / \mathrm{g}$ carbohydrates which is comparitively less (Table 1). A smaller amount carbohydrate may be due to lack of raffinose resulting in hydrolysis of sucrose to supply energy (Mubarak, 2005).

The pre-germinated seeds recorded less protein value $(0.027 \mathrm{mg} / \mathrm{g})$ whereas post germination, protein content increased manifold to $0.207 \mathrm{mg} / \mathrm{g}$ (Table 2). Mung beans contain higher amounts of protein with globulin and albumin as main storage proteins in the seeds (Kirchhoff, 2002). Increase in protein content by germination is attributed to a passive variation.

Dry seeds contained $0.039 \mathrm{mg} / \mathrm{g}$ of amino acids while post germination, maximum amino acid content of $0.239 \mathrm{mg} / \mathrm{g}$ was observed in the seeds (Table 3 ). There was a significant difference between the dry and germinated seeds at $P<0.05$. Thus, a considerable increase in protein and amino acid content was observed post germination in the seeds. They are rich in essential amino acids and proteolytic cleavage of proteins during sprouting further increases the amino acid levels significantly (Tang et al., 2014). The increased amino acid content may be due to synthesis of glutamic acid and other highly active amino acids through the mediation of enzymes in germinating seeds (Sivaramakrishnan and Sarma, 1956).

Table.1 Carbohydrate content in mung bean seeds before and after germination

\begin{tabular}{|c|c|c|}
\hline \multirow{2}{*}{ S. No. } & \multicolumn{2}{|c|}{ Carbohydrate $(\mathbf{m g} / \mathbf{g})$} \\
\cline { 2 - 3 } & Dry seed & Germinated seed \\
\hline 1. & 0.018 & 0.02 \\
\hline 2. & 0.016 & 0.022 \\
\hline 3. & 0.018 & 0.02 \\
\hline Mean \pm S.D & $0.017 \pm 0.001$ & $0.021 \pm 0.001$ \\
\hline
\end{tabular}


Table.2 Protein content in mung bean seeds before and after germination

\begin{tabular}{|c|c|c|}
\hline \multirow{2}{*}{ S. No. } & \multicolumn{2}{|c|}{ Protein $(\mathbf{m g} / \mathbf{g})$} \\
\cline { 2 - 3 } & Dry seed & Germinated seed \\
\hline 1. & 0.026 & 0.206 \\
\hline 2. & 0.028 & 0.208 \\
\hline 3. & 0.026 & 0.206 \\
\hline Mean \pm S.D & $0.027 \pm 0.001$ & $0.207 \pm 0.001$ \\
\hline
\end{tabular}

Table.3 Amino acid content in mung bean seeds before and after germination

\begin{tabular}{|c|c|c|}
\hline \multirow{2}{*}{ S. No. } & \multicolumn{2}{|c|}{ Amino Acid (mg/g) } \\
\cline { 2 - 3 } & Dry seed & Germinated seed \\
\hline 1. & 0.04 & 0.238 \\
\hline 2. & 0.036 & 0.24 \\
\hline 3. & 0.04 & 0.24 \\
\hline Mean \pm S.D & $0.039 \pm 0.002$ & $0.239 \pm 0.001$ \\
\hline
\end{tabular}

Table.4 Variation in fat content in mung bean seeds before and after germination

\begin{tabular}{|c|c|c|}
\hline S. No. & \multicolumn{2}{|c|}{ Total Fat $(\mathbf{m g} / \mathbf{g})$} \\
\hline & Dry seed & Germinated seed \\
\hline 1. & 0.072 & 0.08 \\
\hline 2. & 0.068 & 0.082 \\
\hline 3. & 0.072 & 0.082 \\
\hline Mean \pm S.D & $0.071 \pm 0.002$ & $0.081 \pm 0.001$ \\
\hline
\end{tabular}

Table.5 Chlorophyll a content in mung bean seeds before and after germination

\begin{tabular}{|c|c|c|}
\hline \multirow{2}{*}{ S. No } & \multicolumn{2}{|c|}{ Total Chlorophyll a (mg/g) } \\
\cline { 2 - 3 } & Dry seed & Germinated seed \\
\hline 1. & 0.0093 & 0.01 \\
\hline 2. & 0.0095 & 0.011 \\
\hline 3. & 0.0094 & 0.01 \\
\hline Mean \pm S.D & $0.0094 \pm 0.0001$ & $0.01 \pm 0.0006$ \\
\hline
\end{tabular}

Table.6 Chlorophyll b content in mung bean seeds before and after germination

\begin{tabular}{|c|c|c|}
\hline \multirow{2}{*}{ S. No } & \multicolumn{2}{|c|}{ Total Chlorophyll b $(\mathbf{m g} / \mathbf{g})$} \\
\cline { 2 - 3 } & Dry seed & Germinated seed \\
\hline 1. & 0.0229 & 0.0237 \\
\hline 2. & 0.0228 & 0.0239 \\
\hline 3. & 0.0227 & 0.0238 \\
\hline Mean \pm S.D & $0.0228 \pm 0.0001$ & $0.0238 \pm 0.0001$ \\
\hline
\end{tabular}




\section{Fig.1 Seeds of Mungbean (Vigna radiata) (a) pre-germination (b) post-germination}

(a)

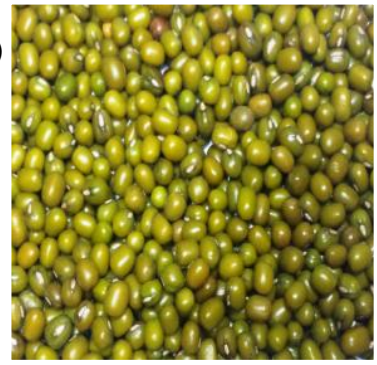

(b)

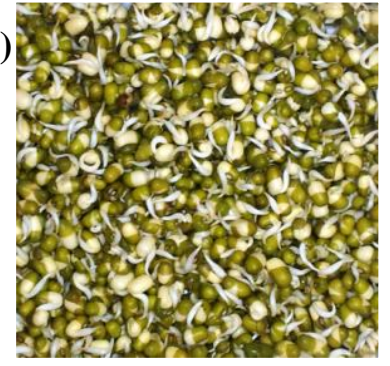

The dry and germinated seeds showed fat content of $0.071 \mathrm{mg} / \mathrm{g}$ and $0.081 \mathrm{mg} / \mathrm{g}$ respectively (Table 4). Changes in fat levels are minimal displaying no significant difference between the two groups. Legumes are naturally low in fat and are particularly free of saturated fat and cholesterol (Polak et al., 2015). Pulses like beans have a low fat content (Fabbri and Crosby, 2016). The low fat content supplies energy and essential fatty acids (Deraz and Khalil, 2008).

Chlorophyll a content was $0.0094 \mathrm{mg} / \mathrm{g}$ and 0.01 $\mathrm{mg} / \mathrm{g}$ during pre and post germination (Table 5). The chlorophyll $b$ value was recorded as 0.0228 $\mathrm{mg} / \mathrm{g}$ and $0.0238 \mathrm{mg} / \mathrm{g}$ in dry and germinated seeds (Table 6). Chlorophyll b was higher than Chlorophyll a both pre and post germination. However, there was no significant difference in chlorophyll a as well as chlorophyll b content between the germinated and dry seeds. The chl a/b ratio did not vary significantly among the two groups. Seed chlorophyll content is reported to have an inverse relationship with the quality as seeds with lower amounts of chlorophyll show high germination rates in the late phase of seed maturation (Jalink et al., 1998).

Thus, it may be suggested that germination of mung bean seedlings is involved in changes in the nutritive contents, biochemical composition, growth parameters and photosynthetic pigments. There was a dramatic increase in proteins and amino acids involving de novo synthesis of new proteins and accumulation of certain existing proteins compared to the dry mung bean seeds. Improved nutritional values of legumes through such techniques have immense importance in alleviation of food crisis. Thus, it is encouraged to increase the consumption of germinated mung beans for enhanced nutrition uptake and disease prevention.

\section{Acknowledgements}

The authors are grateful to and National College, Tiruchirappalli for their constant support and encouragement for successful completion of this work.

\section{References}

Afzal, M. A., Murshad, A. N. M. M., Bakar, M. M. A., Hamid, A. and Salahuddin, A. B. M. 2008. Mungbean Cultivation in Bangladesh, Pulse Research Station, Bangladesh Agricultural Research Institute, Gazipur, Bangladesh, 13.

Arnon, D. I., 1949. Copper enzymes in isolated chloroplasts, polyphenoxidase in beta vulgaris. Plant Physiol. 24: 1-15.

AVRDC, 2012. Mung Bean. Asian Vegetable Research and Development Center-The World Vegetation Center.

Bau, H. M., Villanme, C., Nicolos, J. P. and Mejean, L. 1997. Effect of germination on chemical composition, biochemical constitutes and antinutritional factors of soy bean (Glycine max) seeds. J. Sci. Food Agr. 73: 1-9.

Chang, K. C., and Harrold, R. L. 1988. Changes in selected biochemical components, in vitro protein digestibility and amino acids in two bean cultivars during germination. $J$. Food Sci. 53: 783-787.

Chau, C. F., and Cheung, P. K. 1997. Effect of various processing methods on antinutrients and in vitro digestibility of protein and starch of two Chinese indigenous legume 
seeds. J. Agric. Food Chem. 45 (12): $4773-$ 4776.

Deraj, S. F., and Khalil, A. A. 2008. Strategies to improve protein quality and reduce antinutritional factors in mung bean. Food. 2 (1): 25-38.

Fabbri, D. T. A., and Crosby, G. A. 2016. A review of the impact of preparation and cooking on the nutritional quality of vegetables and legumes. IJGFS. 3: 2-11.

Jalink, H., van der Schoor, R., Frandas, A. and van Pijlen, J. G. 1998. Chlorophyll fluorescence of Brassica oleracea seeds as a non-destructive marker for seed maturity and seed performance. Seed Sci. Res. 8: 437-443.

Kannan, J., 2001. Effects of distillery effluents on crop plants. Advance Plant Science. 14 (1): 127-132.

Kataria, A., Chauhan, B., Punia, D. 1989. Antinutrients and protein digestibility (in vitro) of mungbean as affected by domestic processing and cooking. Food Chem. 32: 917.

Kirchhoff, E., 2002. Online-publication of the german food composition table soucifachmann-kraut on the internet. J. Food. Comp. Anal. 15 (4): 465-472.

Labaneiah, M. E., O. and Luh, B. S. 1981. Changes of starch, crude fiber, and oligosaccharides in germinating dry beans. Cereal Chem. 58: 135-138.

Lowry O. H., Rosebrough N. J., Farr A. L. and Randall R. J. 1951. Protein measurement with the Folin phenol reagent. J. Biol. Chem. 193: 265-275.

Manay, N. S., and Shadaksharaswamy, M. 2001. Foods: facts and principles. New Delhi : New Age. pp: 286.

More, A. D., and Borkar, A. T. 2016. Improvement in Protein and Chlorophyll Content through Physical and Chemical
Mutagens in Phaseolus vulgaris L. Int. J. Curr. Microbiol. App. Sci. 5 (10): 583-591.

Mubarak, A., 2005. Nutritional composition and antinutritional factors of mung bean seeds (Phaseolus aureus) as affected by some home traditional processes. Food Chem. 89: 489-495.

Munoz, G.E., Barlow, P.W. and Palma, B. 1996. Effects of sea water on roots of Prosopis alb (Leguminosae) seedling. Phyton Buenos Aires. 59: 55-63.

Polak, R., Phillips, E. M. and Campbell, A. 2015. Legumes: health benefits and culinary approaches to increase intake. Clin. Diabetes. 33 (4): 198-205.

Sadasivam, S., and Manickam, A. 2008. Biochemical methods. 3rd edn. New Age International Publishers, New Delhi, India.

Salunkhe, D. K., 1982. Legumes in human nutrition. Current status and future research needs. Curr. Sci. 51: 387-394.

Sivaramakrishnan, V. M. and Sarma, P. S. 1956. The metabolism of glutamic acid in germinating green gram seeds. Biochem. $J$. 62: 132-135.

Tang, D., Dong, Y., Ren, H., Li, L. and He, C. 2014. A review of phytochemistry, metabolite changes and medicinal uses of the common food mung bean and its sprouts (Vigna radiata). Chem. Cent. J. 8: 4.

Verma, G., Kumawat, N. and Morya, J. 2017. Nutrient Management in Mungbean [Vigna radiata (L.) Wilczek] for higher production and productivity under semi-arid tract of central India. Int. J. Curr. Microbiol. App. Sci. 6 (7): 488-493.

Yadav, D. L., Jaisani, P. and Pandey, R.N. 2014. Identification of sources of resistance in mungbean genotypes and influence of fungicidal application to powdery mildew epidemics. Int. J. Curr. Microbiol. App. Sci. 3 (2): 513-519.

\section{How to cite this article:}

Inamul Hasan Madar, Amjad Hussain Asangani, Shantkriti Srinivasan, Iftikhar Aslam Tayubi and Gideon I. Ogu. 2017. Nutritional and Biochemical Alterations in Vigna Radiata (Mung Bean) Seeds by Germination. Int.J.Curr.Microbiol.App.Sci. 6(9): 3307-3313. doi: https://doi.org/10.20546/ijcmas.2017.609.408 